\title{
Julevandring og yogakurs. Hvem definerer religion i barnehagen?
}

\author{
Av Ragnhild Laird Iversen og Kari Krogstad
}

Barnehager tilbys vandringer for barn $i$ kirker i forbindelse med jul, og kurs for barn i yoga og meditasjon, av eksterne aktører. Vi har spurt barnehageloererstudenter og deres praksisloerere om de vil takke ja til slike tilbud, og bedt dem begrunne sine svar. Resultatet viser at majoriteten vil takke ja til begge og anser dem verken som religiøs involvering eller uttrykk for religiøs praksis. Vi diskuterer på hvilken måte tilbudene kan betraktes som religion med utgangspunkt $i$ Jonathan $Z$. Smiths stedlige kategorier, og hvem som har definisjonsmakten over hva som er religion og religionsutøvelse i en barnehagekontekst.

Nøkkelord: Barnehage, Den norske kirke, Meditasjon, Religiøs praksis, Yoga

\begin{abstract}
Ragnhild Laird Iversen (f. 1979), Ph.d.-stipendiat Universitetet i Sørøst-Norge. Adresse: Postboks 235, 3603 Kongsberg. E-post: Ragnhild.Iversen@usn.no

Kari Krogstad (f. 1966), førstelektor Universitetet i Sørøst-Norge. Adresse: Postboks 235, 3603 Kongsberg. E-post: kari.krogstad@usn.no
\end{abstract}

\section{INNLEDNING ${ }^{1}$}

Barn i Norge vokser opp i et tros- og livssynsmangfoldig samfunn. Dette gjenspeiles også i barnehagen, og Rammeplan for barnehagens innhold og oppgaver pålegger barnehager å synliggjøre livssynsmangfoldet for at barn skal tilegne seg kunnskap om og forståelse for ulike livsverdener og levesett (Utdanningsdirektoratet 2017: 9). Dette konkretiseres gjennom fagområdet Etikk, religion og filosofi (ERF) som fastslår at personalet skal «skape rom for barnas opplevelser, samtaler, erfaringer og tanker om religion», og gi barn kjennskap til og markere høytider og tradisjoner i den kristne kulturarven (2017: 55). Samtidig er personalet i barnehagen bundet av den menneskerettslige forpliktelsen til å «respektere foreldres [...] frihet til å sørge for sine barns religiøse og moralske oppdragelse i samsvar med deres egen overbevisning» (FN 1966), slik Norge har forpliktet seg til gjennom ratifisering av FNs konvensjon om sivile og politiske rettigheter. Hvilke aktiviteter barnehageansatte mener er egnet i barnehagen, kan påvirke hvilket spillerom barnehagebarnas foreldre får til å definere hva de mener er aktiviteter som er i samsvar med egen religiøs overbevisning.

Barnehager mottar tilbud fra kirker i forbindelse med kristne høytider om

1 Artikkelen bygger på Iversen sin idé og materiale, mens gjennomføring av artikkelskriving, herunder analyse av funn, er felles mellom Iversen og Krogstad.

Prismet - IKO-Forlaget 2020

Tilgjengelig på https://journals.uio.no/index.php/prismet. Publisert under CC BY-NC 4.o. Fagfellevurdert 
kirkevandring, og fra kulturskoler om kurs i yoga og meditasjon i barnehagen. Vi har spurt barnehagelærerstudenter og deres praksislærere om de vil takke ja eller nei til slike tilbud, og hvordan de vil begrunne svaret. Basert på dette undersøker vi følgende problemstillinger: Hvilke refleksjoner gjør barnehagelærere og -studenter seg om kirkevandring og yogakurs er religionsutøvelse i en barnehagekontekst? Og hvordan kan disse refleksjonene påvirke hvem som får utøve definisjonsmakt om religion $i$ barnehagesammenheng?

Eksemplene er basert på forskning om barnehagers bruk av kirkevandringer og en mediedebatt om kurs i yoga og meditasjon for barnehagebarn. Vi vil presentere ulike forståelser av religion og religionsutøvelse i en barnehagekontekst, og så redegjøre for bakgrunnen for eksemplene. Deretter presenterer vi funn fra vårt materiale før vi drøfter det opp mot Jonathan Z. Smiths (2004) kategorisering om at religion kan befinne seg her, der og hvor-som-helst.

\section{RELIGION OG RELIGIONSUTøVELSE \\ I EN BARNEHAGEKONTEKST}

Vårt anliggende med artikkelen er å undersøke hvem som har eller tar definisjonsmakt med hensyn til religion i en barnehagekontekst. Religion er et abstrakt begrep som kan defineres på en rekke ulike måter, både avhengig av sosial kontekst og av hvem som definerer. James A. Beckford (2003) argumenterer for at heller enn å lete etter måter å definere religion på ut fra antagelsen om at religion har gitte generiske kvaliteter, bør en fra et samfunnsvitenskapelig perspektiv heller fokusere på å analysere ulike situasjoner hvor religiøs mening eller betydning konstrueres, tilskrives eller utfordres (s. 16). Det er særlig fenomener som ligger i grenselandet mellom kategoriene religion og ikke-religion som er omdiskutert (Beckford 2003). Fordi det ikke er enighet om hvor grensene mellom disse går, er det relevant å undersøke hvem som i praksis har makten til å definere. Dette er mer enn en akademisk øvelse. I barnehagesammenheng blir grensegang og definisjonsmakt relevant fordi personalet er forpliktet til å jobbe med religion som tema, samtidig som foreldre har rett til å sørge for sine barns religiøse oppdragelse.

Rammeplanen konkretiserer hvordan personalet skal arbeide med religion i barnehagen. Barna skal lære om religion gjennom fortellinger og høytidsmarkering, og de skal få opplevelser og erfaringer med religion som kan forstås som at de skal lære $a v$ religion. Distinksjonen mellom å lære om og $a v$ er ikke tydeliggjort i barnehageloven, i motsetning til opplæringsloven for skolen. Sistnevnte er tydelig på at undervisning i KRLE-faget ikke skal være forkynnende, og presentere «verdsreligionar og livssyn på ein objektiv, kritisk og pluralistisk måte» (Opplæringslova 1998). Spørsmålet er hvilke konsekvenser forskjellen mellom å lære om og av religion bør få for barnehagepersonalets forståelse av hvordan de skal arbeide med religion og hvor grensen for utøvelse av religion går. 
Grensene for hva som anses som religion, utfordres med hensyn til moderne religiøsitet som nyreligiøsitet eller New Age (Selberg 2003). Eksempelvis at kurs i yoga og meditasjon, som har sin bakgrunn i østlige religioner, har blitt transformert til å være ensbetydende med avslapningsteknikker. Kirsten Grønlien Zetterquist og Geir Skeie (2014) drøfter hvordan dette påvirker det svenske skolefaget «livskunskap», som inneholder bl.a. yoga og mindfulness-tenkning. Zetterquist og Skeie stiller spørsmål ved hvorvidt bruk av buddhistisk beslektede mindfulness-programmer kan være uttrykk for en skjult religionsutøvelse, og de hevder at «religiøse fenomener opptrer uten å bli lagt merke til» (s. 305).

Smith (2004) hevder at religion kan forstås ved hjelp av romlige kategorier, og han benevner disse som «here, there and anywhere» (s. 323). I den første kategorien her lokaliserer han religion primært til hjemmet. Med der mener Smith at religion er offentlig og nasjonal, slik det kan komme til uttrykk i kirker eller templer. Den tredje kategorien betegner han som hvor-som-helst, og viser til et rikt mangfold av religiøse former som okkuperer rommet mellom her og der. Dette inkluderer ifølge Smith religiøse entreprenører, og spenner fra grupper vi kaller «foreninger» til aktiviteter vi gir merkelappen «magi» (s. 325).

Et eksempel på kategorien hvor-som-helst er, ifølge en svensk studie av de arenaene der religion forekommer utenfor de etablerte kirker, blant annet som healing, mindfulness, seanser, coaching og kroppsterapier (Frisk og Åkerbäck 2013). Liselotte Frisk og Peter Åkerbäck hevder at grensene mellom hva som er religiøst og ikke-religiøst blir utydelige når slike hverdagspraksiser kan forekomme hvor som helst og uten direkte tilknytning til religion: «Man kan utöva mindfulness eller yoga med inga eller få religiösa inslag, och utan att ens fundera över saken, då frågan om religion förlorat sin aktualitet» (s. 215). Det noen forstår som religion, kan altså befinne seg hvor-som-helst, og uten at de involverte nødvendigvis definerer det som religion. Dette er aktuelt også i en barnehagekontekst.

\section{KRISTENDOM I BARNEHAGEN}

I forskning på hvordan religion arbeides med i utvalgte barnehager, finner vi gjennomgående at barnehageansatte i langt større grad synliggiør kristendom enn minoritetsreligioner (Nilsen 2012; Rosland og Toft 2013; Krogstad og Hidle 2015). Mange barnehager benytter seg av lokalmiljøet, nærmere bestemt Den norske kirke og/eller kristne menigheter, når høytider er på agendaen. Da inviteres barnehager til å komme på såkalt «vandring» hvor kirker eller kristne menigheter har tilpassede opplegg stort sett myntet på de eldste barna. Ifølge en undersøkelse gjennomført av Kari Krogstad (2014), om hvordan barnehager arbeider med jul/advent, oppga 74 prosent av 250 barnehageansatte at de besøker Den norske kirke i forbindelse med jul, mens fire prosent besøker kristne menigheter utenfor Den norske kirke i desember. Det betyr ikke nødvendigvis at kristendom 
vies stor plass i barnehagene. Krogstad (2017) har også undersøkt barnehagelæreres holdninger til aktiviteter knyttet til religion og religiøse høytidsmarkeringer. Hun finner at lærere er redde for å forkynne når temaet er kristne fortellinger, og av den grunn unnlater å snakke med barna om den kristne bakgrunnen for jul. De overlater dette til representanter for Den norske kirke, noe Krogstad omtaler som en «outsourcing» av barnehagenes plikt om å markere kristne høytider jf. rammeplan (2017: 8). Krogstad beskriver også hvordan en julevandring for en barnehage kan foregå i Den norske kirke. Presten forteller barna juleevangeliet, barna synger kristne salmer og kles ut som Maria, Josef og engler når de går sammen med presten til ulike tablåer i kirkerommet som fremstiller julefortellingen (s. 8). Krogstads funn viser at eksterne aktører får ansvar for både å forklare barn bakgrunn for høytiden og å gi barna opplevelser som kan diskuteres med tanke på religiøs involvering. Dette er utgangspunkt for det første caset våre barnehagelærere og studenter ble forelagt. De ble her spurt om de ville takket ja eller nei til en invitasjon fra den lokale kirken om å delta på julevandring.

\section{YOgA OG MEDITASJON I BARNEHAGEN}

I vårt andre case ble informantene bedt om å ta stilling til en invitasjon fra en lokal kulturskole med tilbud om yogakurs. Invitasjonen er basert på en mediedebatt om yoga og meditasjon i en barnehagekontekst, og vi vil bruke denne som utgangspunkt for en beskrivelse av praksiser og som en komponent i vår analyse. I 2016 hadde avisen Varingen en reportasje med tittelen «Lærer yoga i barnehagen». ${ }^{2}$ En yogatime i en lokal barnehage ble beskrevet, og yogalæreren og to av barnehagens pedagogiske ledere ble intervjuet. Yogakurset var formidlet gjennom den lokale kulturskolen, og ifølge avisen hadde syv barnehager benyttet seg av tilbudet. ${ }^{3}$ Journalisten skrev at kursholderen engasjerte barna i yogaøvelser gjennom lekende instruksjoner. Hver time ble avsluttet med meditasjon. Barna, som lot fingrene berøre tommelen, fra lillefinger til pekefinger, satt avslappete og konsentrerte og sang «sa ta na ma», først i fellesskap og siden med instruksjon om å lukke øynene og si ordene inni seg.

Det er ingenting i avisartikkelen som tyder på at yogalæreren eller de pedagogiske lederne anser yoga og meditasjon som religiøs praksis. Samtidig leser vi at yogalæreren instruerer barna i å meditere på et hinduistisk mantra som oversatt betyr noe slikt som «fødsel, død, gjenfødelse», begreper som har en åpenbar tilknytning til en hinduistisk og buddhistisk livsanskuelse. I denne konteksten virker det likevel som at mantraet brukes som vilkårlige ord. Barna forklares ikke hva de betyr, og det giøres ingen refleksjoner over hvorvidt dette er en form for religionsutøvelse.

2 Varingen er lokalavis for Nittedal og Hakadal i Viken fylke.

3 Hver periode innebar én time yoga i uken i åtte uker. 
Avisartikkelen skapte reaksjoner hos en lokalpolitiker som problematiserte om det å synge «sa ta na ma» var opplæring til bønn. Avisen fulgte opp dette i en ny artikkel. I «Kritisk til yoga i barnehagen» (Høidalen 2016a) avviste yogalæreren alle hentydninger til religiøs praksis. Vi får vite $\mathrm{i}$ avisen at foreldrene har blitt informert om tilbudet. De har ikke fått mulighet til å reservere seg, men det har heller ikke kommet negative reaksjoner.

Etter flere innlegg endte debatten med at kommuneadministrasjonen, representert av kulturskolerektoren, leder for pedagogisk-psykologisk tjeneste og barnehageleder, skrev følgende svar til avisen: «Vi mener at tilbudet om yoga for barn ikke har noe religiøst over seg. Vi vil imidlertid drøfte om 'sa ta na ma' bør være en del av dette. Det er fullt mulig å finne andre lyder som gjør samme nytte» (Høidalen 2016b: 3). De konkluderer med at de vil fortsette å tilby yoga til barnehagene, og begrunner dette instrumentelt: «Gjennom å være oppmerksomt til stede i øyeblikket, leve i nuet, og være nær seg selv og menneskene i en snever omkrets, skal barna bli harmoniske og rolige, rustet til å møte en kaotisk verden. Dette er livsfilosofi, ikke religion» (Høidalen 2016b: 3).

Vi finner det interessant hvordan barnehagen og kommuneadministrasjonen vedtar hvorvidt en praksis kan vurderes som religiøs eller ikke. På bakgrunn av debatten og forskning om innhold i barnehagers kirkevandringer, vil vi se nærmere på hvordan barnehagelærere og -studenter vurderer disse spørsmålsstillingene.

\section{Datainnsamling Og METOde}

På en felles samling for 31 praksislærere og 58 studenter ved en barnehagelærerutdanning, ble de tilstedeværende bedt om å svare på et spørreskjema for bruk i forskning og undervisning. De ble gitt følgende to beskrivelser:

Invitasjon 1: Barnehagen mottar et tilbud fra den lokale kirken om å dra på julevandring. Kirken understreker at dette ikke er et misjonsfremstøt, men knytter det til mål i rammeplanen og skriver at dette er en levende måte å laere barna om den kristne julehøytiden. De kan vise til mange positive tilbakemeldinger fra barn som har deltatt. 4

Invitasjon 2: Barnehagen mottar tilbud fra den lokale kulturskolen om å arrangere kurs i yoga og meditasjon i barnehagen. Kursholderne skriver at kurset legger opp til en balansering av kropp og sinn, økt kroppsbevissthet, bedre motorikk og bedre selvfølelse for barna. Arrangøren kan vise til mange positive tilbakemeldinger fra barn som har deltatt. ${ }^{5}$

Formuleringene er bevisst utformet tvetydig og inviterer til aktiviteter vi mener befinner seg i grenselandet for religiøs utøvelse. I invitasjon 1 inviteres barnehagen der, jf. Smith, hvor religion åpenbart finner sted, men kirken understreker at

4 Ordlyden er basert på samtaler og skriftlig informasjon fra en diakon som arrangerer julevandringer.

5 Ordlyden er basert på mediedebatten i Varingen. 
aktiviteten ikke er et misjonsfremstøt, og gir tilbudet en pedagogisk innramming. Et spørsmål er om barnehagen uten videre bør akseptere kirkens definisjon av hva som fremstår misjonerende eller i tråd med rammeplanen. Kirken og barnehagen har i utgangspunktet ulike mandat, og ansvaret for formidling om religion er i rammeplanen gitt barnehagen, ikke religiøse aktører. På den annen side uttrykker rammeplanen at barnehagen skal inkludere nærmiljøet i sine aktiviteter (Utdanningsdirektoratet 2017: 43). Det kan innebære at barnehager velger å besøke lokale kirker, men det er fortsatt barnehagen som har ansvaret for at innholdet $\mathrm{i}$ besøket følger barnehagens rammer.

I invitasjon 2 kommer invitasjonen fra en kulturskole. Innholdet er ikke definert som koblet til religion fra aktørens side, men innebærer praksiser med religiøse røtter som kan forstås ulikt. Slik sett er det et eksempel på at religion i Smiths terminologi kan befinne seg hvor-som-helst. Igjen er det et spørsmål om hvordan respondentene vurderer aktiviteten i et barnehageperspektiv.

Dataene ble samlet inn gjennom et spørreskjema. Her ble deltagerne bedt om å ta stilling til de to invitasjonene ved å krysse av for følgende lukkede svaralternativer: «takker ja», «takker nei», eller «vet ikke», og med mulighet for utdypende kommentarer/begrunnelser. Spørreskjemaet ble besvart av 31 praksislærere og 58 studenter. Utvalget av respondenter er et strategisk utvalg, da alle deltagere var praksislærere og studenter tilhørende et enkelt barnehagelærerutdanningsprogram for det kullet.

I analysen fokuserer vi på de kvalitative elementene ved undersøkelsen, det vil si deltagernes begrunnelser. Disse støttes gjennom oversikter over hvordan de ulike svaralternativene fordeler seg. Analysen av deltagernes begrunnelser ble gjennomført i tråd med Virginia Braun og Victoria Clarke (2006) sine anbefalinger om tematisk analyse. Vår analyse bestod av å lese og gjenlese funn, så kode innholdet $\mathrm{i}$ enheter, identifisere og revurdere temaer. Analysen går fra det deskriptive, hvor data er sortert og organisert for å avdekke viktige mønstre, til tolkningen hvor mønstre blir diskutert i lys av teori og tidligere forskning.

Variasjon i respondentenes erfaringsbakgrunn kan ha påvirket hvordan de har tolket spørsmålsstillingene. Noen av studentenes svar vitner om at de ikke vet hva innholdet $i$ en julevandring er, og deres begrunnelser er preget av dette. Lærernes svar avdekker at flere av dem har erfaring med besøk til Den norske kirke. Denne type vandringer kan utføres på ulike måter, fra enkle rollespill til iscenesettelser som bruker elementer fra gudstjenester med felles bønn og velsignelse. Med hensyn til ulik erfaringsbakgrunn kan deltagerne ha oppfattet invitasjonene ulikt. Undersøkelsen foregikk første semester av studentenes utdanning. De var introdusert for rammeplan for barnehagen og begrepene «feire» og «markere», men hadde ikke hatt undervisning om hvordan disse grensene eventuelt kan vurderes i tilknytning til ulike religioner. 
Når det gjelder reliabilitet, vil våre funn ikke være representative da utvalget på et annet kull av studenter og tilhørende praksislærere ville ha kunne gitt et annet resultat. Men innsikt i hvordan noen lærere og studenter reflekterer over julevandring og yogakurs, kan bidra til refleksjon over praksis og danne grunnlag for mer bevisste valg.

\section{Funn og analyse}

Vi gjengir først resultat fra spørreskjemaets lukkede svaralternativer oppsummert $i$ to tabeller for henholdsvis julevandring (tabell 1) og yoga og meditasjon (tabell 2). Deretter presenterer vi funn fra deltagernes utdypende skriftlige refleksjoner under hver tabell.

\section{Julevandring}

(Tab. 1) Invitasjon 1 «julevandring»

\begin{tabular}{|l|c|c|c|c|}
\hline Deltakere & Takker ja & Takker nei & Vet ikke & Sum \\
\hline Barnehagelærer & 26 & 4 & 1 & 31 \\
\hline Student & 36 & 7 & 15 & 58 \\
\hline Sum & 62 & 11 & 16 & 89 \\
\hline
\end{tabular}

26 av 31 lærere, 84 prosent, krysser av for at de ville takket ja til invitasjonen. De argumenterer med referanse til rammeplanen og fagområdet ERF for å åpne opp for et slikt tilbud, blant annet at Norge har lange kristne tradisjoner, forstått som den kristne kulturarv, som barnehagen har i oppdrag å formidle. Samtidig er det bred enighet blant lærerne om at foreldre skal rådspørres, og at det skal være et alternativt tilbud for de barna hvis foreldre ikke ønsker deltagelse. Flere trekker frem sine erfaringer med at foreldre er positive til slike vandringer.

36 av 58 studenter (62 prosent) vil takke ja. På lik linje med lærerne svarer mange av dem at de tar forbehold om at foreldrene må gi tillatelse og at det må være alternative aktiviteter for dem som ikke ønsker deltagelse. Noen av studentene reflekterer likevel over om formidlingsformen kan være grenseoverskridende. En student skriver: «Det kan muligens være vanskelig for presten å holde seg objektiv i forhold til det budskapet han/hun kommer med. Ved å takke ja til tilbudet må en være sikker på at presten klarer å unngå misjonering, og holder seg til det faglige».

De fire barnehagelærerne (13 prosent) som krysser av for at de vil takke nei, gir ulike begrunnelser. To av dem reflekterer over hvor stor plass det er rett å gi julen som kristen høytid i barnehagen, og konkluderer med at de ikke har tid og kapasitet. En tredje mener at hvis barnehagen takker ja til tilbudet fra kirken, «bør det være i forhold til tradisjoner og hvordan vi 'oppfører' oss når vi er i kirken». Den fjerde begrunner sitt svar med et dilemma: «Jeg vet ikke på forhånd 
om presten vil fortelle eller forkynne». Han mener barnehagen selv er i stand til å formidle kunnskap om julehøytiden. ${ }^{6}$ Læreren legger til at barna uansett er for små, og begrunner dette med at han jobber med 1-2-åringer og mener at julevandring kan bli «julekrabbing for noen».

Syv av studentene (12 prosent) vil takke nei til julevandring. Noen begrunner dette med at de er usikre på om de kan stole på at kirkens representanter kjenner føringene i rammeplanen. Andre er tydelige på at de mener dette krysser grensen mellom feiring og markering. En av studentene begrunner sitt svar med at foreldre vil reagere på involveringen, mens andre skriver at de ikke vet hva foreldregruppen mener om aktiviteten.

Én av praksislærerne krysser av for alternativet «vet ikke». Begrunnelsen er drøftende og vurderer «norsk tradisjon, kultur og religion» opp mot barn som ikke feirer høytiden. 15 studenter krysser av for «vet ikke». Kun én av disse utdyper sitt svar, og reflekterer rundt behovet for mer informasjon, tidsbruk på høytiden, ansvar for å oppsøke andre religioners gudshus, og felles faglig refleksjon på avdelingen. Vedkommende er positiv til julevandring, men legger til at «det er viktig å få frem at det ikke skal være en gudstjeneste».

Flertallet av respondentene, 62 av 89, er positive til tilbudet fra Den norske kirke om julevandring, selv om mange legger inn forbehold om at foreldre må kunne reservere seg. Blant dem som vil takke nei, brukes blant annet begrunnelsen om grensegangen mellom markering og feiring. Det er flere studenter enn praksislærere som er i tvil på om de skal takke ja eller nei. Deres usikkerhet kan skyldes at de ikke har gjort seg erfaringer med slike vandringer, og at de er usikre på hvordan og i hvilken grad de skal samarbeide med barnas foreldre.

\section{Yoga og meditasjon}

(Tab. 2). Invitasjon 2 «yoga og meditasjon»

\begin{tabular}{|l|c|c|c|c|}
\hline Deltakere & Takker ja & Takker nei & Vet ikke & Sum \\
\hline Barnehagelærer & 27 & 0 & 4 & 31 \\
\hline Student & 35 & 10 & 13 & 58 \\
\hline Sum & 62 & 10 & 17 & 89 \\
\hline
\end{tabular}

27 av 31 barnehagelærere (87 prosent) stiller seg positive til dette tilbudet. Mange er enig i behovet slik det fremstilles i ordlyden i invitasjonen om at barn må lære «å roe ned». Følgende skriftlige begrunnelser er eksempler på en positiv innstilling: «Har stor tro på yoga for barn, særlig i dagens hverdag hvor man skal rekke så mye». «Barna lærer sammenheng mellom kropp og sinn. Det øker læring og

6 Vi har i enkelte tilfeller valgt å angi kjønn på respondentene. De ble ikke bedt om å krysse av for kjønn på spørreskjemaet, da denne kategorien ikke ble vurdert som hensiktsmessig for analysen. Der hvor «han» eller «hun» oppgis, er det altså tilfeldig valgt av oss. 
helhetlig utvikling». «Noen barn kan trenge å lære seg å puste med magen». Fem av lærerne skriver i sine begrunnelser for å takke ja at de ville ha spurt barnas foresatte om innspill. En av lærerne, som oppgir at hun tidligere har jobbet som trosopplærer i Den norske kirke, skriver at selv om hun har positive erfaringer med begge former for aktiviteter, bør det innhentes samtykke fra foreldrene og gis mulighet for reservasjon i begge tilfeller. Vi finner det av interesse at hun er en av få som reflekterer over at yoga og meditasjon også kan være involverende praksiser.

En av barnehagelærerne reflekterer eksplisitt rundt forholdet mellom yoga/ meditasjon og julevandring, og ser dem som vesensforskjellige når det kommer til religiøse koblinger. Han skriver: «Barnehagen avgjør på vegne av alle, så ingen grunn til å reservere seg. Julevandring har med religion å gjøre og er litt mer ømtålig i forhold til yoga/meditasjon». En annen ser behovet for å undersøke forankringen av yogaen og meditasjonen nærmere, og skriver: «Dette tilbudet virker ikke religiøst forankret, men viktig å sjekke ut i forkant».

35 av 58 studenter ( 60 prosent) vurderer yoga og meditasjon som en passende aktivitet i en barnehagekontekst. I likhet med lærerne gjengir flere av dem ordlyden $\mathrm{i}$ invitasjonen i sin begrunnelse. Flere studenter er eksplisitte på at mens de finner det vanskelig å vurdere tilbudet om julevandring grunnet religiøse koblinger, er valget om å takke ja til yoga og meditasjon lett. En student skriver: «Yoga og meditasjon er ikke noe rituale og derfor noe man kan gjøre i barnehagen uten at noen kan si nei på grunn av religion. Julen er mer merket som religion, man tenker kanskje ikke på yoga og meditasjon som å tilhøre noe».

Ingen av barnehagelærerne takker nei til invitasjonen, men i sine skriftlige svar reflekterer noen av dem over at de ville ha stilt praktiske spørsmål rundt alderstilpasning, varighet, økonomi og innpassing i avdelingens fokusområder. Ti av 58 studenter (17 prosent) takker nei. Deres motforestillinger handler primært om at de stiller seg tvilende til om aktiviteten kan tilpasses barns alder tilstrekkelig, eller om aktiviteten stiller for høye krav til koordinasjon, konsentrasjon og stillesitting.

Flere av studentene skriver at selv om yoga og meditasjon har religiøse røtter, ser de ikke denne aktiviteten som noen form for religiøs praksis. En student skriver: «Yoga er en tradisjon innenfor hinduisme. Men den kan ikke ses på som en bønn. Formålet med yoga er 'balansering av kropp og sinn, økt kroppsbevissthet' og ikke å komme i kontakt med 'Gud'».

Henholdsvis fire av 31 lærere (13 prosent) og 13 av 58 studenter (22 prosent) krysser av for alternativet «vet ikke». Flere av begrunnelsene inntar en drøftende form. Eksempelvis skriver en student: «På den ene siden kan aktiviteten virke lite tilpasset energiske små barn, på den andre siden er det spennende å prøve noe nytt og det skader ikke å prøve». En annen student reflekterer over at tilbudet ikke «inngår» i rammeplanen, samtidig som vedkommende vurderer om det kan 
knyttes opp mot en buddhistisk høytidsmarkering. Det er interessant at studenten mener aktiviteten blir mer relevant om den kobles tydeligere mot religion. Blant de usikre studentene er det også tre som stiller spørsmål ved hva foreldrene mener, og en som begrunner dette med at tilbudet i «utgangspunktet er et religiøst ritual».

Flertallet av respondentene, 62 av 89, er positive til tilbudet fra kulturskolen om kurs i yoga og meditasjon. Ingen av lærerne vil takke nei, og kun fem av dem mener at foreldre bør kunne reservere seg mot slike aktiviteter. Studentene er noe mer skeptiske til yoga i barnehagen. Dette handler likevel i begrenset grad om vurderinger knyttet til yogaens potensielle koblinger til religion. Ti studenter vil takke nei, hovedsakelig begrunnet $i$ at aktivitetene kan være en fysisk utfordring for barn. 13 av studentene er i tvil på om de skal takke ja eller nei, og deres refleksjoner spenner fra å handle om aldersmessig egnethet til om foreldrene bør rådspørres. Enkelte undrer seg også over om yoga kan kobles til religion.

\section{DEFINISJONER OG VURDERINGER AV RELIGIØS PRAKSIS I EN BARNEHAGEKONTEKST}

Samlet sett stiller flertallet av studenter og lærere seg positive til både julevandring og meditasjon/yoga. Tallmessig er det nærmest like mange som oppgir å ville takke ja til begge aktiviteter. Det betyr ikke nødvendigvis at respondentene inntar en prinsipiell stilling for eller imot eksterne tilbud og behandler dem likt. På tross av at aktivitetene blir presentert i sammenheng av samme undersøkelse, spriker mange av respondentene i sine svar i hvordan de vil vurdere de ulike forespørslene, og det er særlig blant studentene det i stor grad er forskjellige vurderinger som vist til i tabell 3 .

(Tab. 3). Samsvar mellom vurderinger

\begin{tabular}{|l|c|c|c|}
\hline Deltakere & $\begin{array}{c}\text { Svarer det samme } \\
\text { på begge tilbud }\end{array}$ & Svarer ulikt på tilbudene & Sum \\
\hline Barnehagelærer & 23 & 8 & 31 \\
\hline Student & 23 & 35 & 58 \\
\hline Sum & 46 & 43 & 89 \\
\hline
\end{tabular}

I begge grupper er mange opptatt av at det er opp til foreldre å velge om barnet skal delta på julevandring. Det er likevel en tydelig forskjell $i$ at barnehagelærerne ser det som uproblematisk å dele barnegruppen, mens studentene i noe større grad stiller seg nølende til dette.

Flertallet av deltagerne er positive til julevandring. Våre respondenter begrunner sitt ja til julevandring med at Norge har lange kristne tradisjoner som barnehagen har i oppdrag å formidle, forstått som den kristne kulturarv. Dette er i overensstemmelse med Krogstad (2017) som hevder at barnehagelærere kan oppfatte kristne (og spesielt lutherske) høytider som uttrykk for norske kultur- 
tradisjoner fremfor som religiøse ritualer, og at disse høytidene dermed heller reflekterer samfunnets tradisjoner.

Julevandring kan være et eksempel på at religion fortsatt er der, for å bruke Smiths terminologi. Som Krogstad (2017) viser til i sine beskrivelser av hva som skjer på en julevandring med barnehagebarn i regi av en lokal representant for Den norske kirke, kan julevandring forstås som et uttrykk for Smiths kategori som religion der, i kirken. Det innebærer at det er kirken som definerer den religiøse praksisen myntet på barnehagebarn. Vandringen er på kirkens premisser og kan dermed ikke være nøytral eller ikke-religiøs. Kirken skal ikke forkynne overfor barnehagebarn. Dette er et dilemma, både for kirken som tilbyr vandringer, men også for barnehagens personale som takker ja, med hensyn til hvor grensen mellom formidling og forkynnelse skal gå.

Rammeplanen definerer ikke hva som er religiøs praksis i barnehagen, og bruker begrepet «markering», ikke feiring, i forbindelse med religioners høytider. I dette ligger en innholdsmessig vesensforskjell. Å feire regnes som familiers private anliggende og kan innebære utøvelse av ulike ritualer. En markering er derimot en pedagogisk aktivitet hvor målet er å lære om, ikke utøve religion. Flere respondenter reflekterer over denne krevende motsetningen. Samtidig svarer flertallet av lærerne og studentene at de vil takke ja til tilbudet, uten å vise refleksjon over kirkens rolle som formidler. Dette er tankevekkende. Det kan virke som om at flere av våre barnehagelærere og -studenter tar lett på oppgaven å definere rammene rundt høytidsmarkeringer. Om ikke barnehagen tar pedagogisk grep, risikerer de at kirkens selvpresentasjon blir stående, uten å bli belyst på kritiske eller pluralistiske måter. I ytterste konsekvens er dette en abdisering av det pedagogiske ansvaret fra barnehageaktørenes side, og en overgivelse av definisjonsmakt rundt religionens grenser til en religiøs aktør.

Flere studenter enn lærere vil enten takke nei til tilbudet om julevandring eller er usikre på om de skal takke ja eller nei. De begrunner dette med at en slik vandring nettopp krysser grensen mellom markering og feiring, og reflekterer dermed over hvem som definerer hva som anses som religiøs praksis i en barnehagekontekst. Kirkens religiøse formidling (forkynnelse) er noe annet enn barnehagens formidling av religiøse fortellinger med et pedagogisk siktemål. Det kan være stor forskjell i kirkelig praksis, eksempelvis at noen kirkelig ansatte ser virksomhet rettet mot barnehagen som en naturlig forlengelse av trosopplæringsarbeidet, mens andre reflekterer over hvordan de kan fortelle som ikke strider mot rammeplanenes mandat og dermed har et pedagogisk siktemål. Det er likevel en prinsipiell hovedforskjell mellom barnehagen og kirken som aktør, da kirkens ansatte og formidlere representerer en religiøs institusjon med en uttalt kristen forankring. Dermed kan grenseoppgangen mellom religiøs formidling og allmennpedagogisk formidling diskuteres. Et mindretall av lærere og studenter 
viser denne typen refleksjoner.

I Varingens avisartikler anser hverken yogalæreren, de pedagogiske lederne eller kommuneadministrasjonen yoga og meditasjon som religiøs praksis, men som livsfilosofi. Barna instrueres til å meditere over mantraet «sa ta na ma» med begrunnelse om at dette er hvile, konsentrasjon, at barna roer ned og har det gøy, samt avspenning, balanse og tilstedeværelse. I møte med kritiske spørsmål om dette kan anses som religionsutøvelse avviser barnehagen dette, og kommuneadministrasjonen fastslår at tilbudet om yoga ikke har noe religiøst over seg. Bruken av et religiøst mantra vurderes riktignok erstattet med andre ord, men det virker ikke som administrasjonen er åpen for at det er ulike måter å vurdere om yoga har religiøse koblinger på. Deres definisjonsmakt avgjør dermed i dette tilfellet hva som skal regnes som religiøs praksis eller ikke i kommunens barnehager.

I vår konstruerte invitasjon 2 er det en kulturskole som er tilbyder. Den er ikke en tros- og livssynsaktør, og det kan ha medvirket til at respondentene er positive til tilbudet og i liten grad reflekterer over at selve innholdet kan ha noe med religiøs praksis å gjøre. Det at få av våre respondentene anser yoga og meditasjon som religiøs utøvelse, kan være et uttrykk for sekularisering og privat religiøsitet. Det kan også forstås slik Frisk og Åkerbäck (2013) hevder, at grensene mellom hva som er religiøst og ikke-religiøst blir utydelige. Dermed kan kulturskolens tilbud om kurs i yoga og meditasjon være noe som kan forekomme hvor-som-helst jf. Smith, også i barnehagen, og uten direkte tilknytning til religion. Samtidig kan meditasjon og yoga vurderes som religionsrelaterte aktiviteter. I avisartiklene i Varingen ble det gjengitt hvordan barna ble instruert $\mathrm{i} a ̊$ uttale det religiøse mantraet «sa ta na ma», som er tydelige eksempler på «rester» av religion i en praksis som av utøveren oppfattes som tømt for sitt opprinnelige religiøse innhold. Våre informanters vurderinger kan derfor ses å samsvare med Zetterquist og Skeies (2014) funn om at bruk av buddhistisk beslektede mindfulness-programmer kan være uttrykk for en skjult religionsutøvelse, og at religiøse fenomener opptrer uten å bli lagt merke til. Spørsmålet blir igjen hvem som har definisjonsmakten. Når profesjonsutøvere i barnehagen definerer hvordan gråsonefenomener skal vurderes, fratas samtidig foreldre muligheten til å kunne vurdere eller kommunisere hvilke vurderinger de mener er rett for sitt barn.

\footnotetext{
Avslutining

Vi stiller spørsmål ved om hvor grensen går mellom at barn får kunnskap om religion i barnehagen til at de utøver religion i regi av eksterne aktører. Våre funn og påfølgende analyse viser at flertallet av barnehagelærerne og -studentene i vår undersøkelse er positive til tilbud fra ulike aktører som ønsker innpass $i$ barnehagen. Deres prinsipielle refleksjoner om å takke nei eller være tvilende til tilbudene heller mer mot praktiske motforestillinger som eksempelvis tid og at
} 
barn fysisk ikke vil klare å være i ro. Sett opp mot rammeplanens krav om at personalet kun skal gi barn kjennskap til, opplevelser og erfaringer med religioner, finner vi dette av interesse. Barn skal ikke utøve religion i en barnehagekontekst, men som våre funn viser, er flertallet positive til at andre enn dem selv står for tilbud som vi mener befinner seg i grenselandet for religiøs utøvelse. Dette kan påvirke hvordan foreldre med ulikt syn på disse vurderingene møtes. I forbindelse med julevandring, som kan sees som en tydelig markert religiøs aktivitet hvor barnehagen går der religion er, vil riktignok mange gi foreldrene definisjonsmakt til å reservere egne barn. Det er derimot få som problematiserer at barnegruppen da deles etter foreldrenes religiøse overbevisning. Barnehagelærernes vurderinger kan også medvirke til at eksterne aktører får definisjonsmakt over aktiviteter som kan befinne seg i et grenseland mellom lek og religionsutøvelse.

Religion i en barnehagekontekst ligger i grenselandet mellom å lære om hva religion er og å utøve religion. Denne grensegangen er en utfordring å vurdere for barnehagelærere og -studenter. Mange av dem åpner for religionsutøvelse både når religionen er der, som på julevandring $\mathrm{i}$ kirken, og når den er hvor-som-helst gjennom sekulariserte praksiser som yoga og meditasjon.

Barnehagelærerutdanningen må bidra til at profesjonsutøvere skal kunne ta kvalifiserte avgjørelser basert på kunnskap. Dette gjelder eksempelvis når barnehagen får tilbud fra eksterne aktører som vedrører spørsmål om foreldres rettigheter til å bestemme over sitt barns religiøsitet, men også hva som kan anses som tilslutning til en religion og/eller religiøs utøvelse. Det kan innebære at kristne høytider oppfattes som en del av samfunnets sekulære tradisjoner uten at det stilles spørsmål ved om det er riktig at Den norske kirke står for kunnskapsformidlingen, mens tilbud om aktiviteter som yoga og meditasjon kategorisk kvalifiserer til å være ikke-religion, og dermed kun teknikker for å «roe barn ned». Her bør barnehagelærerutdanningen bidra til at studentene får kunnskap om ulike perspektiver på aktivitetene, bevissthet rundt foreldres mulighet til medvirkning i disse vurderingene, og refleksjon rundt balansering av både majoritets- og minoritetsforeldres ønsker og rettigheter. Samtidig kan det være en utfordring for studentene å overføre sin teoretiske kunnskap til en barnehagehverdag med allerede etablerte praksiser, som til dels kan utfordre prinsipiell tenkning over hvem som bør definere religion i en barnehagekontekst.

\section{LitTERATUR}

Barnehageloven. 2005. Lov om barnehager (LOV-2005-06-17-64). Tilgjengelig: https://lovdata.no/lov/2005-06-17-64

Beckford, James A. 2003. Social theory and religion. Cambridge: Cambridge University Press.

Braun, Virginia og Clarke, Victoria. 2006. «Using thematic analysis in psychology.» 
Qualitativ Research in Psychology, 3(2), 77-101.

FN-Sambandet. 1966. Konvensjon om sivile og politiske rettigheter. Tilgjengelig: https://www.fn.no/Om-FN/Avtaler/Menneskerettigheter/Konvensjon-omsivile-og-politiske-rettigheter

Frisk, Liselotte og Åkerbäck, Peter. 2013. Den mediterande dalahästen. Religion på nya arenor $i$ samtidens Sverige. Stockholm: Dialogos Förlag.

Høidalen, Sigbjørn. 2016a, 3. juni. «Kritisk til yoga i barnehagen.» Varingen, s. 3.

Høidalen, Sigbjørn. 2016b, 13. juli. «Vurderer å kutte sa ta na ma.» Varingen, s. 3.

Krogstad, Kari og Hidle, Kari-Mette Walmann. 2015. «Høytidsmarkering i religiøst mangfoldige barnehager.» Tidsskrift for Nordisk Barnehageforskning, 9(6). doi: https://doi.org/10.7577/nbf.1007

Krogstad, Kari. 2014. «Høytidsmarkering i barnehagen.» Tidsskriftet FoU i praksis, 8(2), s. 51- 69.

Krogstad, Kari. 2017. «Religious Festivals in Early Childhood Education and Care (ECEC) Institutions. A Norwegian Case Study.» Tidsskrift for Nordisk Barnehageforskning, 16(3). doi: https://doi.org/10.7577/nbf.2158

Nilsen, Tina Dykesteen. 2012. «Barnehagen - kultur for læring om religioner og livssyn?» i Vist, Torill og Alvestad, Marit (red.) Læringskulturer i barnehagen. Flerfagligeforskningsperspektiver(s. 239-260). Oslo: Cappelen Damm Akademisk.

Opplæringslova. 1998. Lov om grunnskolen og den vidaregåande opplæringa (LOV-1998-07-17-61). Tilgjengelig: https://lovdata.no/dokument/NL/ lov/1998-07-17-61

Rosland, Kristine Toft og Toft, Audun. 2013. «Markering av minoriteters høytider i barnehagen. En undersøkelse av forholdet mellom rammeplan og praksis» i Pareliussen, Ingar, Moen, Bente Bolme, Reinertsen, Anne Beate og Solhaug, Trond (red.) FoU i praksis 2012. Conference proceedings (s. 216-223). Tilgjengelig: https://nordopen.nord.no/nord-xmlui/handle/11250/145883

Seiff, Liv. 2016, 27. mai. «Lærer yoga i barnehagen.» Varingen, s. 14-15.

Selberg, Torunn. 2003. «Religion smurt tynt utover» i Lund-Olsen, Tone og Repstad, Pål (red.) Forankring eller frikopling? Kulturperspektiver på religiøst liv i dag (s. 45-62). Kulturstudier nr. 33. Bergen: Program for kulturstudier, Norges forskningsråd Høyskoleforlaget.

Smith, Jonathan Z. 2004. Relating Religion. Essays in the Study of Religion. Chicago: University of Chicago Press.

Utdanningsdirektoratet. 2017. Rammeplan for barnehagens innhold og oppgaver. Tilgjengelig: https://www.udir.no/globalassets/filer/barnehage/ rammeplan/rammeplan-for-barnehagen-bokmal2017.pdf.

Zetterqvist, Kirsten Grønlien og Skeie, Geir. 2014. «Religion i skolen; her, der og hvor-som-helst.» Norsk pedagogisk tidsskrift, 98(05), s. 305-315. 